\title{
GIS and SBF for estimating groundwater recharge of a mountainous basin in the Wu River watershed, Taiwan
}

\author{
Hsin-Fu Yeh ${ }^{1}$, Hung-I Lin ${ }^{1}$, Shing-Tsz LeE ${ }^{1}$, Min-Hsiang Chang ${ }^{2}$, \\ Kuo-Chin Hsu ${ }^{1}$ and Cheng-Haw LeE ${ }^{1, *}$ \\ ${ }^{1}$ Department of Resources Engineering, National Cheng Kung University, Tainan 701, Taiwan. \\ ${ }^{2}$ Central Geological Survey, Ministry of Economic Affairs, New Taipei 235, Taiwan. \\ *Corresponding author.e-mail: leech@mail.ncku.edu.tw
}

The temporal and spatial distributions of precipitation are extremely uneven; so, careful management of water resources in Taiwan is crucial. The long-term overexploitation of groundwater resources poses a challenge to water resource management in Taiwan. However, assessing groundwater resources in mountainous basins is challenging due to limited information. In this study, a geographic information system (GIS) and stable base-flow (SBF) techniques were used to assess the characteristics of groundwater recharge considering the Wu River watershed in central Taiwan as a study area. First, a GIS approach was used to integrate five contributing factors: lithology, land cover/land use, lineaments, drainage, and slope. The weights of factors contributing to the groundwater recharge were obtained from aerial photos, geological maps, a land use database, and field verification. Second, the SBF was used to estimate the groundwater recharge in a mountainous basin scale. The concept of the SBF technique was to separate the base-flow from the total streamflow discharge in order to obtain a measure of groundwater recharge. The SBF technique has the advantage of integrating groundwater recharge across an entire basin without complex hydro-geologic modelling and detailed knowledge of the soil characteristics. In this study, our approach for estimating recharge provides not only an estimate of how much water becomes groundwater, but also explains the characteristics of a potential groundwater recharge zone.

\section{Introduction}

Most of the annual precipitation $(2500 \mathrm{~mm})$ in Taiwan comes from typhoons and convection rain. Due to the complex topography and the occurrence of monsoons, the distribution of precipitation is not uniform in regard to either time or space. In general, the annual precipitation in the mountainous and eastern coastal areas $(3000 \mathrm{~mm})$ is higher than that in the plains and western coastal areas (1500-2000 mm). The precipitation is concentrated in the wet season, which accounts for $62 \%$ of the total precipitation in northern Taiwan. The wet season accounts for $70-80 \%$ of total precipitation in central Taiwan and over 90\% in the south. Thus, the temporal and spatial distributions of precipitation are extremely uneven, making careful management of water resources in Taiwan crucial.

Precipitation is a major water source for Taiwan; it has a direct impact on the ecological environment and the quality of life. The trend of precipitation characteristics in Taiwan is negatively influenced by climate warming, which has gradually led to imbalance in distribution of water resources (Hsu et al. 2007).

Long-term overexploitation of groundwater resources poses a challenge to water resource management in Taiwan. Figure 1 shows the trend for

Keywords. Groundwater recharge; GIS; SBF; Taiwan. 


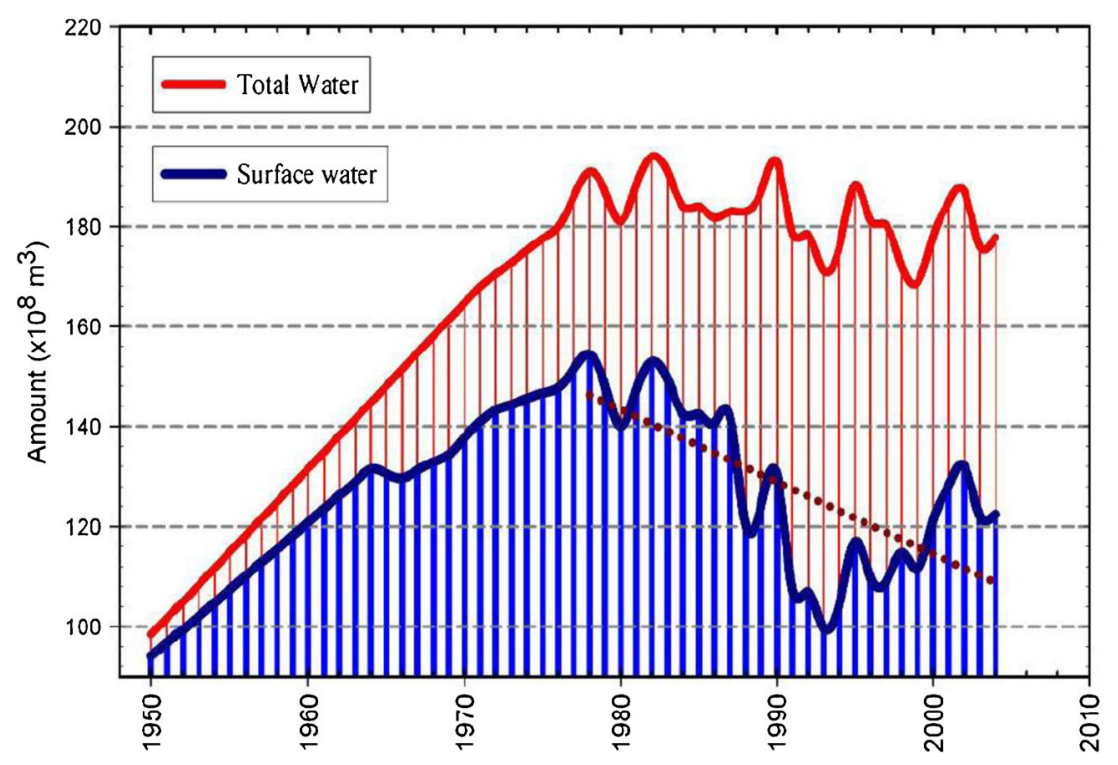

Figure 1. Surface water and total water consumption between 1950 and 2004; dashed line indicates the declining trend for surface water use (Wang 2007).

total water consumption and surface water from 1950 to 2004 in Taiwan (Water Resources Agency 2005). Total water consumption rose until early $1980 \mathrm{~s}$, increasing from 9.8 billion $\mathrm{m}^{3}$ to 19.4 billion $\mathrm{m}^{3}$ from 1950 to early 1980s. Since the mid 1980 s, the amount of groundwater consumption in Taiwan per year has increased and exceeds natural recharge of groundwater due to decreased streamflow and an associated decrease in the use of surface water for human consumption. The problem became worse in the early 1990s. Overexploited areas are concentrated in the central-southern agricultural regions, where groundwater consumption is the highest (Wang 2007).

The main factors causing groundwater level declines is decreased recharge coupled with increased groundwater pumping. Currently, a longterm downward trend in the groundwater level can be seen in all regions except for the Taipei Basin and Hualien-Taitung Valley, which verifies the decrease in groundwater storage (Wang et al. 2004). The downward trend is a warning signal for declining groundwater storage.

Groundwater recharge refers to the entry of water from the unsaturated zone into the saturated zone below the water table surface, together with the associated flow away from the water table within the saturated zone (Freeze and Cherry 1979). Recharge occurs when water flows past the groundwater level and infiltrates into the saturated zone. It is an extremely important water component of the circulation cycle in nature. Many factors affect the occurrence and movement of groundwater in a region, including topography, lithology, geological structures, depth of weathering, extent of fractures, primary porosity, secondary porosity, slope, drainage patterns, landform, land use/cover, and climate (Mukherjee 1996; Jaiswal et al. 2003; Jha et al. 2007). In-site hydrogeology experiments and geophysics surveys help to explain the groundwater recharge process and help evaluate the spatial-temporal differences in study regions. However, these surveys often focus on a single affecting factor or an indirect site-specific experiment for groundwater recharge, reducing the reliability of the explanation. Recently, remote sensing (RS) has been increasingly employed to replace on-site exploration or experiments. RS not only provides a wide-range scale of the space-time distribution of observations, but also saves time and money (Murthy 2000; Leblanc et al. 2003; Saraf et al. 2004; Solomon and Quiel 2006; Jha et al. 2007; Tweed et al. 2007; Chowdary et al. 2008, 2010; Rahman 2008; Gupta and Srivastava 2010; Preeja et al. 2011; Choi et al. 2012). Sener et al. (2005) pointed out that RS can effectively identify the characteristics of the surface of the earth (such as lineaments and geology) and can also be used to examine groundwater recharge.

RS technology, such as aerial photos, was used in the present study to identify the geological features, topography, and distribution of the rivers in the region under consideration. Additionally, the land utilization survey database, geologic maps, and on-site investigation were adopted to quantitatively and qualitatively describe the hydrogeological conditions of the area. The different polygons in the thematic maps were labeled 
separately. The influence of the factors of groundwater recharge and the interaction between the factors were examined. Weighting values were assigned according to the on-site situation. The distribution of the groundwater recharge potential zone was determined by coordinating it with the space integrating function of the GIS.

The groundwater recharge potential zone has been assessed by various methods and in many countries (Krishnamurthy et al. 1996; Saraf and Choudhury 1998; Shahid et al. 2000; Jaiswal et al. 2003; Sener et al. 2005; Shaban et al. 2006; Dinesh Kumar et al. 2007; Tweed et al. 2007; Chowdary et al. 2008; Rahman 2008; Chenini et al. 2010; Machiwal et al. 2011; Mukherjee et al. 2012; Forkuor et al. 2013; Jang et al. 2013). In this study, the weights of different factors for potential groundwater recharge and the scores obtained under various characteristics were referred using the study methods of Shaban et al. (2006) and Yeh et al. (2009).

In addition, the concept of stable base-flow (SBF) model was to use the base-flow separation from the total streamflow discharge to obtain a measure of groundwater recharge. This established the relationship between the rate of recharge and the controlling physical properties of basins. The method described in this study was intended for the analysis of the groundwater flow system of a basin for which a stream gauging station at the downstream end can be considered the only point of outflow. For most applications, it should be reasonable to assume that all or nearly all of the groundwater in the basin discharges into the stream, except for that which is lost by evapotranspiration or human activity (Chen and Lee 2003; Lee et al. 2006; Stewart et al. 2007; McCallum et al. 2010; Eckhardt 2012; O'Brien et al. 2013). The area of contribution in the groundwater system is equal to the surface drainage area for the purpose of expressing flow in units of specific discharge (Rutledge 1998). Base-flow separation has been shown to be a viable means of estimating recharge using a streamflow drainage system to integrate a hydrologic response over the entire drainage watershed, thus reducing the problem of site specificity (Arnold and Allen 1999).

However, assessing groundwater resources in a mountainous island such as Taiwan is challenging due to limited information. Therefore, it is important to thoroughly understand Taiwan's groundwater resources in order to enhance the efficiency and performance of the planning, utilization, administration, and management of their water resources. Very limited information, such as precipitation, river flux, hydrogeological properties, groundwater consumption, and groundwater recharge, is available for the mountainous island of Taiwan.
The assessment of groundwater resources is particularly difficult for islands. In this study, a geographic information system (GIS) and stable base-flow (SBF) techniques were used to assess groundwater recharge within the Wu River watershed. This study used lithology, land use/cover, lineaments, drainage, and slope as the five significant factors affecting potential groundwater recharge. GIS technology was used to digitize both hydrologic and geographic information, and a fundamental database was constructed. SBF was established to estimate the groundwater recharge in a mountainous basin scale, and SBF was developed in this study to obtain more reliable results. Evaluating the potential groundwater recharge of this area can help determine the groundwater recharge characteristics in Taiwan's mountain region for the goal of water resource protection.

\section{Study area}

The study area, the Wu River watershed, is located in the central part of Taiwan. The basin encompasses an area of about $2025 \mathrm{~km}^{2}$. The length of the river is about $119.1 \mathrm{~km}$, and it lies between the longitudes $120^{\circ} 28^{\prime} 57^{\prime \prime}$ and $121^{\circ} 16^{\prime} 21^{\prime \prime} \mathrm{E}$ and latitudes $23^{\circ} 48^{\prime} 04^{\prime \prime}$ and $24^{\circ} 16^{\prime} 47^{\prime \prime} \mathrm{N}$. Figure 2 shows the geographical location of the Wu River basin. The research region belongs to the tropical marine climate, with a mean annual temperature of $22.5^{\circ} \mathrm{C}$ and an average annual precipitation for 2001-2010 of $2400 \mathrm{~mm} /$ year. During the summer, southwest monsoons occur, and typhoons bring heavy rainfall. The northeast monsoon brings vapour from the Pacific Ocean during the winter. Because water vapour is blocked by the Central Mountains of Taiwan, there is little rainfall in the winter. Therefore, the wet and dry seasons are very distinct in this region. The wet season is from April to September, and the dry season is from October to March.

\section{Methodology}

\subsection{Mapping potential groundwater recharge zone}

In this study, the weights of different factors for potential groundwater recharge and the score under various characteristics were assessed based on the characteristics of the study area. The factors influencing groundwater recharge, and their relative importance, were compiled from previous literature (Shaban et al. 2006; Yeh et al. 2009). Duplicate factors were combined, and only representative factors were extracted. This study used lithology, land use/cover, lineaments, drainage, and slope as the five significant factors affecting 


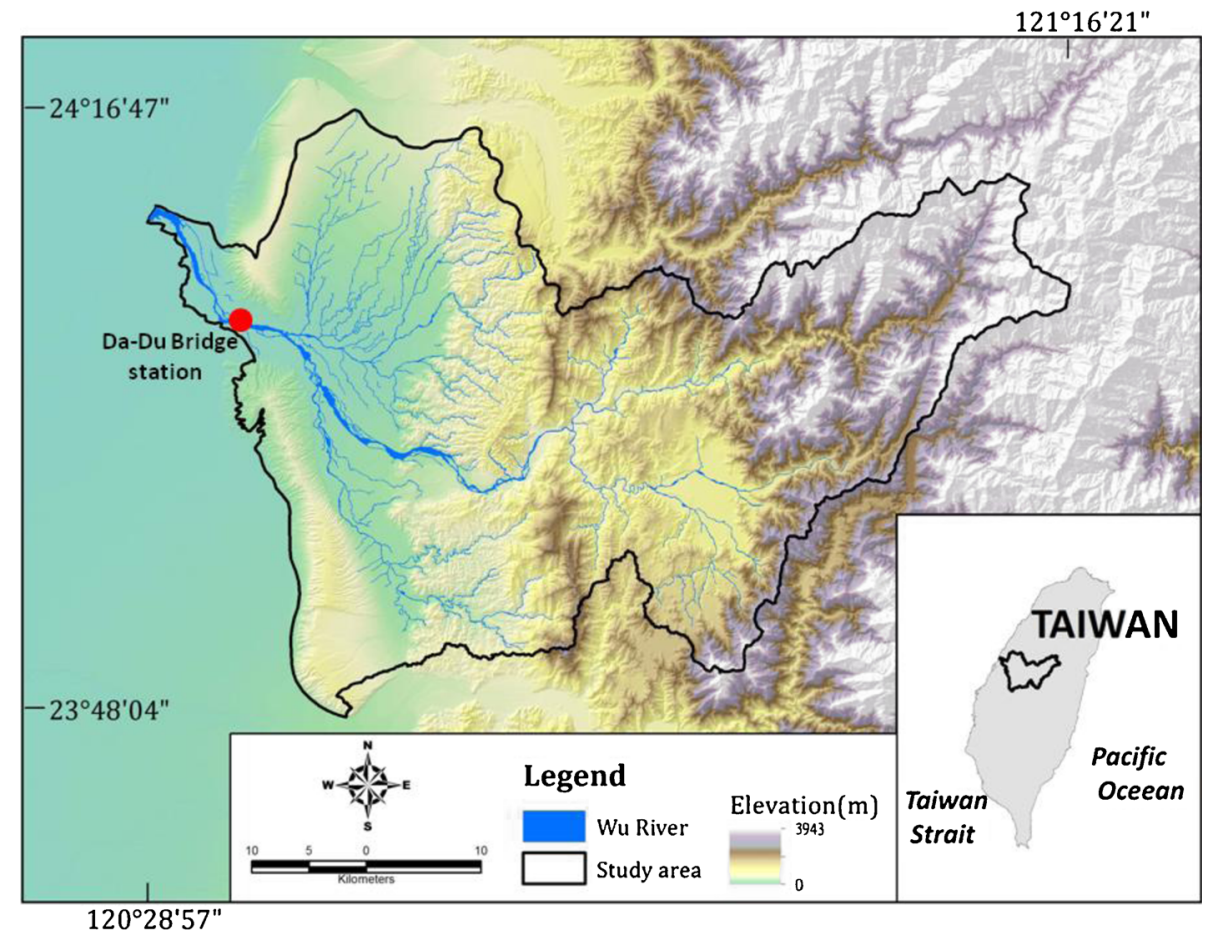

Figure 2. Geographic location of the Wu River watershed in Taiwan, showing gauging station.

potential groundwater recharge. GIS technology was used to digitize the hydrologic and geographic information, and a fundamental database was constructed. Appropriate scores were set for different factors. Finally, the spatial analysis function was used to demonstrate the potential groundwater recharge zone of the research area. Figure 3 illustrates the flowchart of this investigation.

\subsubsection{Establishing potentially related groundwater recharge factors}

Lithology: Shaban et al. (2006) pointed out that the type of rock exposed to the surface significantly affects groundwater recharge. Lithology affects the groundwater recharge by controlling the percolation of water flow (El-Baz and Himida 1995). Although some investigations have ignored this factor by regarding the lineaments and drainage characters as a function of primary and secondary porosity, this study includes lithology to reduce uncertainty in determining lineaments and drainage. The $1 / 250,000$ geological map of Taiwan is used to describe the lithology in this study.

Land use/cover: Land use/cover is an important factor in groundwater recharge. It includes the type of soil deposits, the distribution of residential areas, and vegetation cover. Shaban et al. (2006)

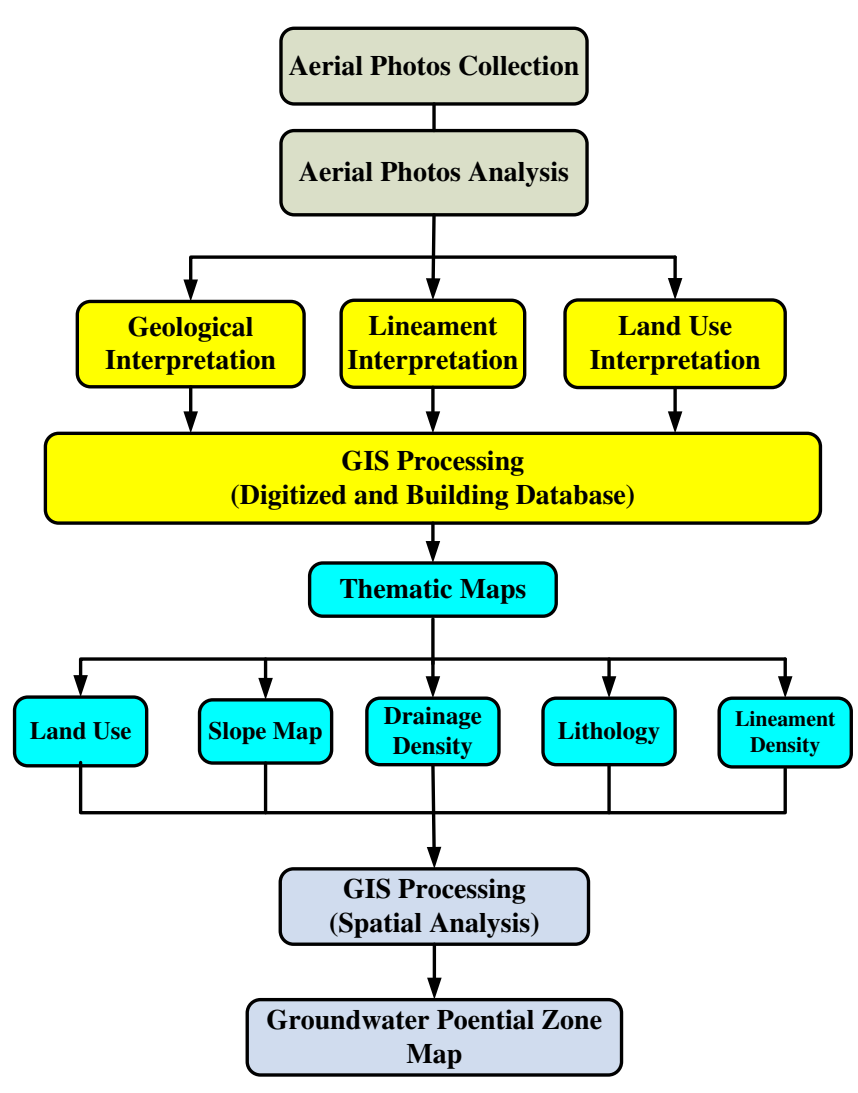

Figure 3. Methodology flowchart for the potential groundwater zone. 
concluded that vegetation cover benefits groundwater recharge in the following ways:

- Biological decomposition of the roots helps loosen the rock and soil so that water can percolate to the surface of the earth easily.

- Vegetation prevents direct evaporation of water from soil.

- The roots of a plant can absorb water, thus preventing water loss. Leduc et al. (2001) estimated the difference in the amount of groundwater recharge due to changes of land utilization and vegetation from changes in the groundwater level. Land use/cover is included in this study as an important factor affecting the groundwater recharge process. The land use/cover of the study watershed is assessed in accordance with the Territory Utilization Status Survey Database established by the Land Administration Bureau of the Taiwan Provincial Government.

Lineaments: The analysis of lineaments has been applied extensively to explain geological status since geological images were first utilized in the 1930s. Lineaments are generally referred to in the analysis of remote sensing of fractures or structures. Lineament photos from satellites and aerial photos have similar characteristics, but the results of the explanation in situ may be different. O'Leary et al. (1976) defined lineaments as the simple and complex linear properties of geological structures, such as faults, cleavages, fractures, and various surfaces of discontinuity, that are arranged in a straight line or a slight curve, as detected by remote sensing. Many nongeological structures, such as roads and channels, cause errors in the analysis of lineaments. Therefore, geologic maps and on-site investigations must be used to eliminate possible errors. Lineaments may be used to infer groundwater movement and storage. Lattman and Parizek (1964) were the first to adopt a lineament map to explore groundwater. Thereafter, many scholars have applied this approach in complicated geological regions (Solomon and Quiel 2006). The present study used lineament-length density $\left(L_{d}\right)\left[\mathrm{L}^{-1}\right]$ (Greenbaum 1985), which represents the total length of lineaments in a unit area as:

$$
L_{d}=\frac{\sum_{i=1}^{n} L_{i}}{A}
$$

where $\sum_{i=1}^{n} L_{i}$ denotes the total length of lineaments $[\mathrm{L}]$, and $A$ denotes the unit area $\left[\mathrm{L}^{2}\right]$. A high lineament-length density infers high secondary porosity, thus indicating a zone with high levels of potential groundwater recharge.
Drainage: The structural analysis of a drainage network helps assess the characteristics of a groundwater recharge zone. The quality of a drainage network depends on lithology, which provides an important index of the percolation rate. The drainage-length density $\left(D_{d}\right)\left[\mathrm{L}^{-1}\right]$, as defined by Greenbaum (1985), indicates the total drainagelength in a unit area, and is determined by:

$$
D_{d}=\frac{\sum_{i=1}^{n} S_{i}}{A}
$$

where $\sum_{i=1}^{n} S_{i}$ denotes the total length of drainage [L], and $A$ denotes the unit area $\left[\mathrm{L}^{2}\right]$. The drainagelength density is significantly correlated with the groundwater recharge: a zone with a high drainagelength density has a high level of groundwater recharge. Many studies have integrated lineaments and drainage maps to infer a potential groundwater recharge zone (Edet et al. 1998; Shaban et al. 2006).

Slope: Rainfall is the main source of groundwater recharge in both tropic and subtropic regions. The slope gradient directly influences the infiltration of rainfall. Larger slopes produce a smaller recharge because water flows rapidly down a steep slope during rainfall, so it does not have sufficient time to infiltrate the surface and recharge the saturated zone. The slope analysis function in the GIS is used to assess the variation of slope in the study basin using data from the Digital Terrain Model (DTM) database in Taiwan.

\subsubsection{Establishment of relationships among potential groundwater recharge factors}

During the process of recharge, groundwater recharge factors do not have the same influence, and not every factor is independent (Shaban et al. 2006). When calculating potential groundwater recharge, these factors were used for evaluation, and weight accumulation was applied to get a recharge potential score. Recharge potential $P_{r}$ can be expressed as:

$$
P_{r}=\sum w_{i} r_{i},
$$

where $w_{i}$ is the $i$ th factor weight [-]; $r_{i}$ is the $i$ th factor rate [-], and the subscripts $i$ refer to the individual features of a theme.

The weight of a factor represents the proportion of its value in the potential recharge scale. For a large-scale study area, the potential recharge value cannot be tested and verified, so the score weight of the recharge potential must be subjectively determined according to the importance of each factor during the recharge process. Thus, the higher the 
Table 1. Recharge potential factor weights obtained from Shaban et al. (2006) and Yeh et al. (2009).

\begin{tabular}{|c|c|c|c|}
\hline Factor & Weight & Rate & $\begin{array}{c}\text { Assigned } \\
\text { weight }\end{array}$ \\
\hline \multirow[t]{5}{*}{ Lineaments density } & 10 & 2.0 & 20 \\
\hline & 8 & & 16 \\
\hline & 6.5 & & 13 \\
\hline & 5 & & 10 \\
\hline & 5 & & 10 \\
\hline \multirow[t]{5}{*}{ Drainage density } & 8 & 1.5 & 12 \\
\hline & 6.5 & & 9.75 \\
\hline & 5 & & 7.5 \\
\hline & 3.5 & & 5.25 \\
\hline & 2 & & 3 \\
\hline \multirow[t]{5}{*}{ Lithology } & 10 & 3.0 & 30 \\
\hline & 8 & & 24 \\
\hline & 5 & & 15 \\
\hline & 2 & & 6 \\
\hline & 1 & & 3 \\
\hline \multirow[t]{4}{*}{ Slope gradient } & 10 & 1.5 & 15 \\
\hline & 8 & & 12 \\
\hline & 6.5 & & 9.75 \\
\hline & 5 & & 7.5 \\
\hline \multirow[t]{5}{*}{ Land use/cover } & 6.5 & 2.5 & 16.25 \\
\hline & 5 & & 12.5 \\
\hline & 3.5 & & 8.75 \\
\hline & 2 & & 5 \\
\hline & 1 & & 2.5 \\
\hline
\end{tabular}

Note: Assigned weight $=$ weight $\times$ rate. Weight modified from Shaban et al. (2006), rate cited from Yeh et al. (2009).

recharge weight, the larger the influence of the factor. Each of the contributing factors has a degree of positive or negative effect in terms of groundwater recharge. Therefore, five major descriptive levels were given, ranging from very high to very low. Proposed weighting of these levels starts from a maximum of 10 points to the minimum level of 1 point. This study referred to the study methods of Shaban et al. (2006) and Yeh et al. (2009). The factor weights are shown in table 1.

This study used the influential factor diagram of groundwater recharge potential (figure 4) drawn by Yeh et al. (2009). In the diagram, there were primary influential relationships and secondary influential relationships among the factors. Each relationship was weighted according to its strength. The representative weight of a factor of recharge potential was the sum of all weights from each factor. A high weight indicated that the factor had a large influence on groundwater recharge. If a primary influential relationship existed among factors, then a weight of 1.0 was assigned. If a secondary influential relationship existed among factors, then a weight of 0.5 was assigned. The weights for each factor were added together to

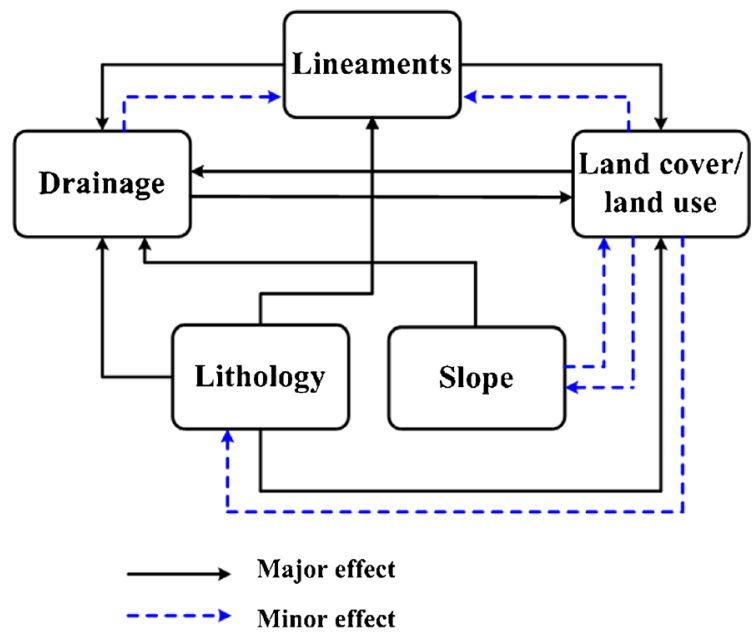

Figure 4. The interactive influence of factors concerning the recharge property (Yeh et al. 2009).

Table 2. Relative rates for each factor.

\begin{tabular}{lrc}
\hline Factor & Calculation & $\begin{array}{c}\text { Proposed } \\
\text { relative rates }\end{array}$ \\
\hline Lithology & $3 \times 1.0=3.0$ & 3.0 \\
Land cover/use & $1 \times 1.0+3 \times 0.5=2.5$ & 2.5 \\
Lineaments & $2 \times 1.0=2.0$ & 2.0 \\
Drainage & $1 \times 1.0+1 \times 0.5=1.5$ & 1.5 \\
Slope & $1 \times 1.0+1 \times 0.5=1.5$ & 1.5 \\
& & $\Sigma 10.5$ \\
\hline
\end{tabular}

obtain the recharge potential factor weight. For example, there was a primary influential relationship among the lithology factor and the lineament, drainage, and land use/cover factors; thus, the weight for the lithology factor was set to 3.0. The results are shown in table 2. In this study, satellite images were used to analyze the completed digital map and to set appropriate influential scores according to influential factors. The superposition principle was used to determine recharge potential scores for all locations in the study area (figure 5) to serve as the reference for division.

\subsection{Quantifying groundwater recharge: The stable base-flow (SBF) model}

Various techniques have been used to estimate a record of groundwater discharge under the streamflow hydrograph. Most of these techniques involve a considerable degree of subjectivity with regard to their applications. Horton (1933) described a method of shifting a horizontally 'normal depletion-curve' across a hydrograph. It is noted that segments of the hydrograph which coincide with this curve represent periods of streamflow 


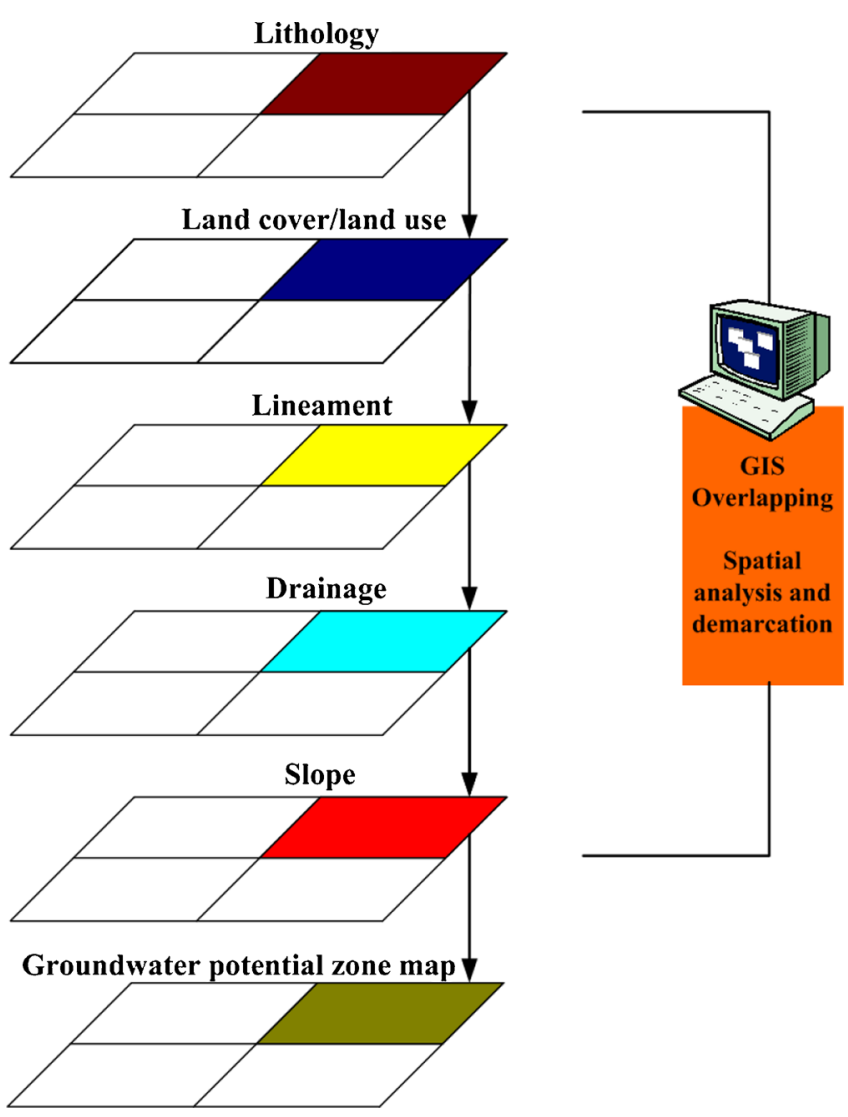

Figure 5. GIS technology used in spatial integration and analysis to demarcate basin potential groundwater recharge zone.

equal to groundwater discharge. Thus, estimating groundwater discharge during periods of surface runoff can be done by simply connecting the points where the hydrograph departs from the normal depletion curve. Barnes (1939) separated surface flow, storm seepage, and base-flow by assigning a distinct 'depletion factor' to each part. Kulandaiswamy and Seetharaman (1969) pointed out that Barnes' method may not separate streamflow into three parts reliably, and they separated the hydrograph into direct runoff and base-flow. In some applications, investigators have used characteristic curves of groundwater discharge in conjunction with records of precipitation, snowfall, temperature, and groundwater levels (Olmsted and Hely 1962).

Cherkauer and Ansari (2005) pointed out that base-flow separation involves developing a simple groundwater budget equation for a small basin:

$$
I+G W_{\mathrm{in}}=Q_{\mathrm{bf}}+G W_{\mathrm{out}}+E T+N P+\frac{\Delta S}{t},
$$

where $I$ is the infiltration to the system $\left[\mathrm{L} \mathrm{T}^{-1}\right]$; $G W_{\text {in }}$ is the groundwater influx to the basin through an aquifer $\left[\mathrm{L} \mathrm{T}^{-1}\right] ; Q_{\mathrm{bf}}$ is the groundwater discharge to the streamflow base-flow $\left[\mathrm{L} \mathrm{T}^{-1}\right]$;
$G W_{\text {out }}$ is the groundwater efflux from the basin through an aquifer $\left[\mathrm{L} \mathrm{T}^{-1}\right] ; E T$ is the evapotranspiration losses from the basin $\left[\mathrm{L} \mathrm{T}^{-1}\right] ; N P$ is the net pump of groundwater by people into or out of the basin $\left[\mathrm{L} \mathrm{T}^{-1}\right]$, and $\Delta S / t$ is the rate of change of groundwater storage with respect to time $\left[\mathrm{L} \mathrm{T}^{-1}\right]$.

If watersheds can be selected where $G W_{\text {in }}=$ $G W_{\text {out }}=N P=\Delta S / t=0$, and if recharge is defined as net groundwater recharge $(I-E T)$, then equation (4) reduces to

$$
\begin{aligned}
\text { Recharge } & =\text { Net recharge }=Q_{\mathrm{bf}} \\
& =\text { Streamflow base-flow } .
\end{aligned}
$$

Flow as complete groundwater discharge (while surface runoff is negligible) can be based on the antecedent recession. Linsley et al. (1982) proposed the following empirical relationship:

$$
N=A^{0.2}
$$

This relationship gives the time base of surface runoff $(N)[\mathrm{T}]$ as a function of the drainage area $(A)\left[\mathrm{L}^{2}\right]$ upstream from a stream gauging station, in square miles. Equation (6) is a simple relationship that may not be reliable in all hydrologic systems.

The time of surface runoff might involve other variables in addition to the drainage area, such as the channel slope and physiographic setting. Although little information on the time of surface runoff is available from the literature on this topic, the concept of lag-time might be useful because it has been related to various watershed properties, including channel slope. From unithydrograph theory, lag-time is defined as the time from the centroid of the rainfall excess to the centroid of the runoff hydrograph. Lag-time is generally considered to be constant for a basin. The time base of the surface runoff is the number of days after a peak in the streamflow hydrograph while the component of flow attributed to surface runoff (including the bulk of interflow) is considered negligible. A part of the streamflow hydrograph may thus be considered completely to be groundwater discharge if it is preceded by a period of recession equal to or greater than $N$.

The base-flow estimation explained here is a form of streamflow partitioning. Rutledge (1992) first developed this method based on the antecedent streamflow recession. The principles of this method are as follows: (1) Daily streamflow data is required. (2) Linear interpolation is used to estimate groundwater discharge during the surface runoff period. There are some basic assumptions of this model: (1) surface runoff and base-flow are the two main components of streamflow; interflow is out of consideration; (2) the groundwater table is invariable; natural factors, such as evapotranspiration, precipitation, and human-induced 
factors, do not affect the water level; (3) the evapotranspiration of saturated zone approaches zero; (4) the aquifer is underlain by impermeable material; its side boundaries are vertical and have no flow crossing them.

Detailed steps of the method for base-flow estimation can be found in previous studies (Chen and Lee 2003; Lee et al. 2006). The requirement of the antecedent recession is met for the day in question if for the part of the daily mean streamflow record that includes all days that precede the day in question by $N$ days or less, the stream flow on each of these days is greater than or equal to the streamflow on the day that follows, where $N$ is the time base of surface runoff.

To prevent overestimation caused by rainstorm events, Rutledge $(1993,1998,2000)$ suggested that wintertime recession data be chosen to represent the behaviour of the recession characteristic. Zektser (2002) indicated that the lowest two monthly base-flows should be chosen to be the average value of the year in some cases. For this purpose, an alternative method, the SBF, is developed in this study to obtain more reliable results. The diagram of the SBF analysis according to our previous study, and based on the topographic and climatic conditions in Taiwan, is shown in figure 6 (Chen and Lee 2003; Lee et al. 2006, 2008). The procedure of the SBF analysis is as follows:

- Obtain the monthly base-flow from the base-flow record estimation.

- Obtain the long-term mean monthly base-flow.

- Perform data processing by sorting and accumulating the long-term mean monthly base-flow to obtain a new series of long-term mean monthly accumulated base-flows.
- Choose the most stable (near-linear) segment and obtain the slope of the stable base-flow. To avoid overestimating the results, the largest monthly values (minimally adjusted requirements for each gauging station) should not be chosen.

- Use linear interpolation on the remaining months to obtain the mean annual base-flow.

\section{Results and discussion}

\subsection{Spatial analysis of potential groundwater zone}

The distribution of factors was determined using the recharge potential factor maps of the study area. The division standard of Shaban et al. (2006) and Yeh et al. (2009) was used to define the weight division standard of every recharge factor in the study area, as shown in table 3. According to the division standard, the area was divided into 500 $\times 500 \mathrm{~m}$ squares, and the weight was calculated according to every factor in a given square. The five factor maps obtained using this method is described below.

\subsubsection{Analysis of the types of lithology}

The 1/250,000 geological map of Taiwan surveyed in 2004 revealed that the upstream region of the $\mathrm{Wu}$ River watershed was mainly composed of a mix of sandstone with slate and phyllite (45.5\%). In the midstream region, the basin mainly consists of sandstone with thick/thin shale from the Lushan Formation (32\%). The downstream region was mainly composed of gravelly sand (22.5\%). The gravelly sand in the downstream provides

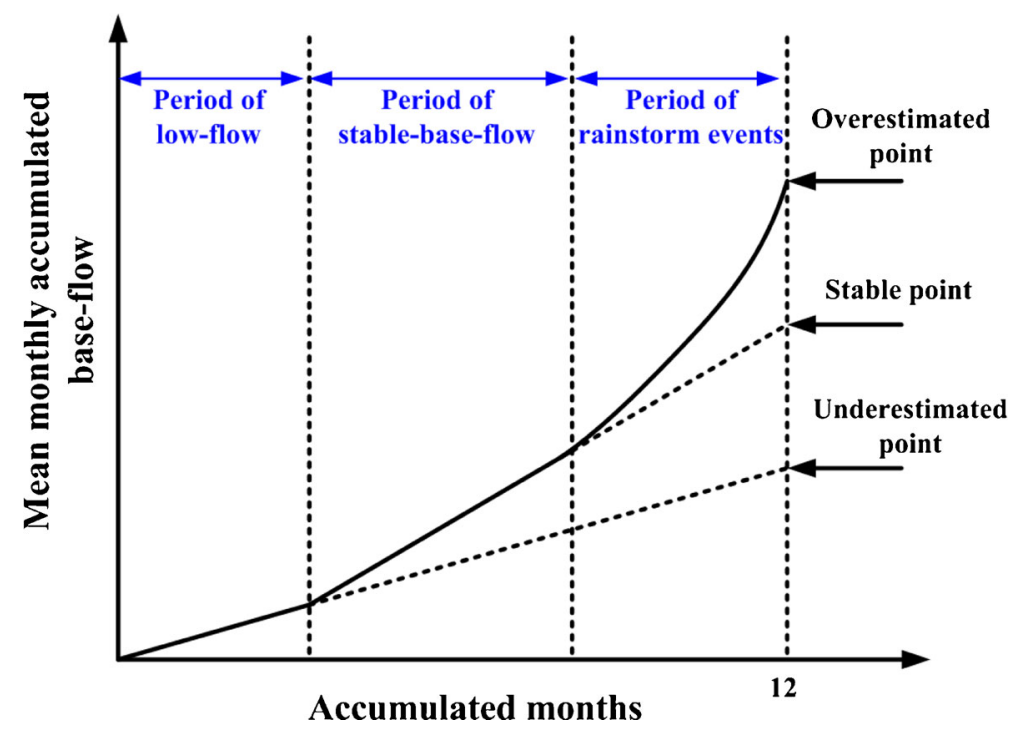

Figure 6. The diagram of the stable base-flow analysis (Lee et al. 2006). 
Table 3. Categorization of factors influencing recharge potential in the $W u$ River watershed.

\begin{tabular}{|c|c|c|}
\hline Factor & Domain of effect & Proposed weight \\
\hline \multirow[t]{6}{*}{ Lineaments density } & $5-6\left(\right.$ segment $\left./ \mathrm{km}^{2}\right)$ & 10 \\
\hline & $5-4$ & 8 \\
\hline & $4-3$ & 6.5 \\
\hline & $3-2$ & 5 \\
\hline & $0-2$ & 3 \\
\hline & 0 & 0 \\
\hline \multirow[t]{6}{*}{ Drainage density } & $10-15$ (segment $\left./ \mathrm{km}^{2}\right)$ & 8 \\
\hline & $6-10$ & 6.5 \\
\hline & $4-6$ & 5 \\
\hline & $2-4$ & 3.5 \\
\hline & $0-2$ & 2 \\
\hline & 0 & 0 \\
\hline \multirow[t]{5}{*}{ Lithology } & Gravelly sand & 10 \\
\hline & Sandstone, slate and phyllite & 8 \\
\hline & Sand-shale alternation (sandstone) & 5 \\
\hline & Sand-shale alternation (shale) & 2 \\
\hline & Shale & 1 \\
\hline \multirow[t]{4}{*}{ Slope gradient } & $0-10^{\circ}$ & 10 \\
\hline & $10-20^{\circ}$ & 8 \\
\hline & $20-35^{\circ}$ & 6.5 \\
\hline & $35-60^{\circ}$ & 5 \\
\hline \multirow[t]{5}{*}{ Land use/cover } & Surface water body/river channel & 6.5 \\
\hline & Agricultural land & 5 \\
\hline & Bare land & 3.5 \\
\hline & Forest & 2 \\
\hline & Building & 1 \\
\hline
\end{tabular}

excellent regions for percolation. The data indicates that the valleys had higher scores due to alluvial fans. Figure 7(a) shows the distribution of lithology in the study area.

\subsubsection{Analysis of land use/cover}

The land use/cover of the study watershed was assessed in accordance with the Territory Utilization Status Survey Database established by the Land Administration Bureau of the Taiwan Provincial Government (2006). The information was obtained from the original map of the territory utilization survey drawn by the Land Administration Office of the counties and cities. In the urban planning districts, $1 / 500,1 / 600,1 / 1000$ or $1 / 1200$ cadastral maps were used as the base maps. In the nonurban planning districts, the $1 / 5000$ farming map from the Agriculture and Food Agency was used as the base map. The total area for the study watershed was approximately $2025 \mathrm{~km}^{2}$. The mountain area occupies around $1520 \mathrm{~km}^{2}$, i.e., $75 \%$ of the watershed. Most of the mountain area, which was forest land covered by vegetation, was located in the midstream and upstream. This reduces runoff and increases the recharge. The level ground was mainly distributed in the downstream alluvial plain and in fragmentary small terraces along the riverbank. The scores indicate that the study area was mainly composed of forest land (62.8\%), agricultural land (21.8\%), river valley distribution, bare land, land under construction $(10.8 \%)$, and river channel and surface water bodies $(4.6 \%)$. The factor potential distribution of land use and cover of the study area are shown in figure $7(\mathrm{~b})$.

\subsubsection{Analysis of lineament-length density}

For the assessment of the lineaments of study watershed, a stereoscope was used to interpret the aerial photos from an agricultural aerial survey from 1996 to 2000, which was verified on-site. A computer algorithm was used to obtain the feature lines of a topographic chart. The lineament-length density of the completed linear structure map and the structure line obtained by the Central Geological Survey, Ministry of Economic Affairs (MOEA), was then calculated. The scores showed that the lineaments were more densely distributed in the east of the study area, mainly due to the land elevation of this area being higher. The development 

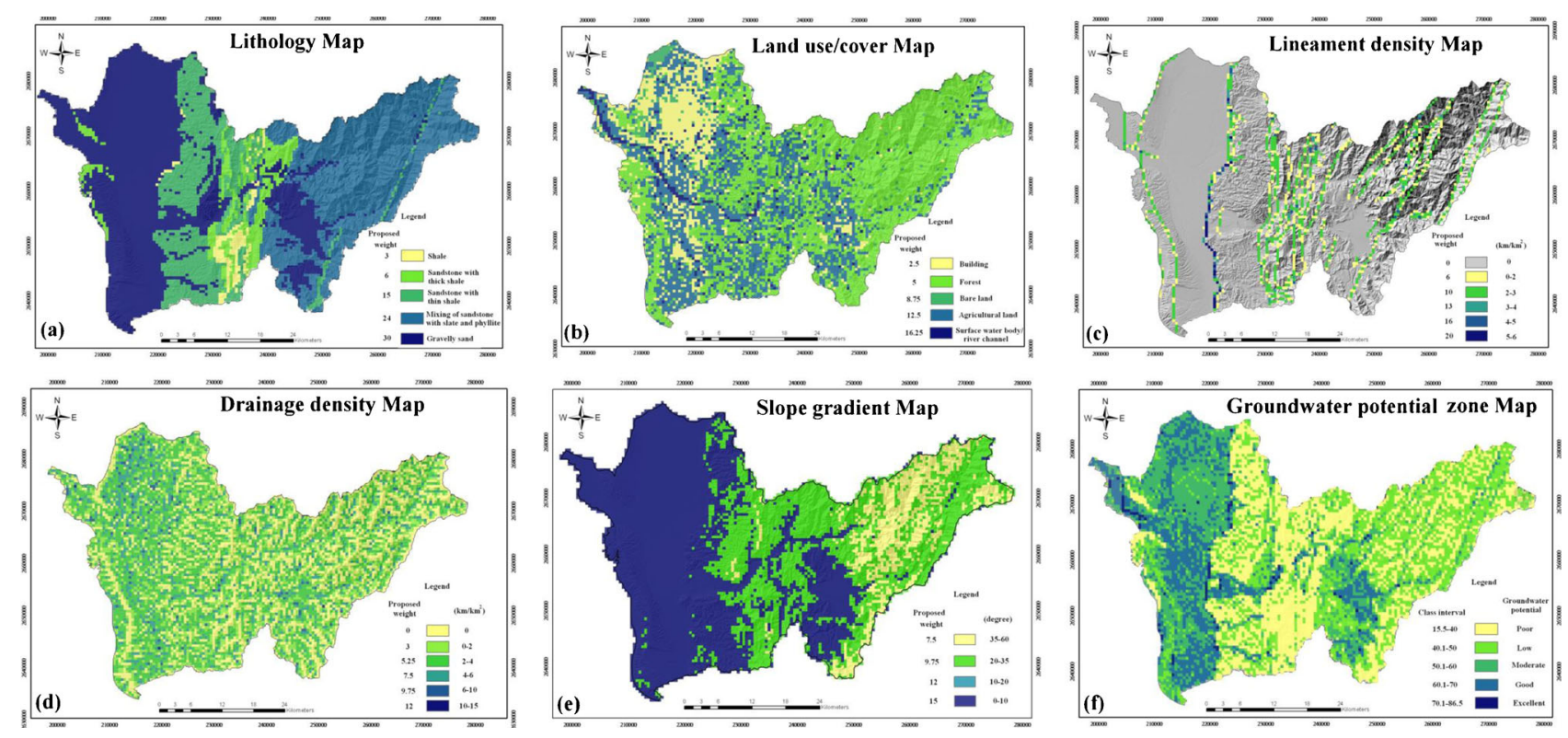

Figure 7. Thematic maps for Wu River watershed prepared using GIS: (a) lithology map; (b) land use/cover map; (c) lineament density map; (d) drainage density map; (e) slope gradient map and (f) groundwater potential zone map.

of river system has caused serious erosion downstream, so the lineament-length density was higher. The main distribution area of the length-density value of the lineament-length density was found to be $0-2 \mathrm{~km} / \mathrm{km}^{2}$, and the second was $2-3 \mathrm{~km} / \mathrm{km}^{2}$. Figure 7(c) depicts the lineament-length density diagram of the study area.

\subsubsection{Analysis of drainage-length density}

The distribution of drainage in the study watershed was determined using the aerial photos of an agricultural aerial survey undertaken from 19962000. The study basin can be roughly divided into dendritic and grid drainage patterns. The dendritic drainage pattern was distributed mostly in the northeast region of the watershed, while the southeast was mainly grid drainage. The dendritic drainage pattern was influenced more by lithology than by the structure of the area. The drainagelength density was often larger than $2.0 \mathrm{~km} / \mathrm{km}^{2}$, making the region an excellent percolation recharge zone. The distribution range of the drainage-length density was mainly between $0-2 \mathrm{~km} / \mathrm{km}^{2}(55.6 \%)$, followed by $2-4 \mathrm{~km} / \mathrm{km}^{2}(22.7 \%)$. The evaluation of drainage-length density potential is shown in figure $7(\mathrm{~d})$.

\subsubsection{Analysis of slope}

The slope analysis function in the GIS was used to assess the variation of slope in the study basin using data from the Digital Terrain Model (DTM) database in Taiwan (2004). The Council of
Agriculture authorized the Aerial Survey Office of Forestry Bureau to measure and to produce the digital terrain information used in this study. Three-dimensional aerial photos with regular $40 \mathrm{~m}$ sampling intervals were applied. The study basin was part of a mountainous area. The division results show that the east region of the area was steep and thus unfavourable for infiltration. The slope became less and less steep towards the west. The precipitous terrain caused rapid runoff, and did not store water easily. A small part of the downstream was fairly gentle, so the time for percolation was longer. Since the terrain varies significantly, the factor slope varies inversely with the groundwater recharge. Figure 7(e) illustrates the distribution of slopes in the study area.

\subsubsection{Demarcation of the groundwater recharge zone}

In this study, for the purpose of calculating potential groundwater recharge, the factors were used for evaluation, and weight accumulation was applied to get a recharge potential score. The total weights of different polygons in the integrated layer were computed using a weighted linear combination method as follows:

$$
\begin{aligned}
P_{r}= & L D_{w} L D_{r}+D D_{w} D D_{r}+L G_{w} L G_{r} \\
& +S G_{w} S G_{r}+L C_{w} L C_{r}
\end{aligned}
$$

where $P_{r}$ is the groundwater recharge potential index [-]; $L D$ is the score of lineaments density [-]; $D D$ is the score of drainage density [-]; $L G$ is the score of lithology [-]; $S G$ is the score of slope 
gradient [-]; $L C$ is the score of land use/cover [-], and the subscripts $w$ and $r$ refer to the weight of a theme and the rate of individual features of a theme, respectively.

Our results demonstrate that the potential groundwater recharge zone in this basin can be divided into five grades, namely excellent, good, moderate, low, and poor, based on the analysis of the five factors for potential groundwater recharge. The analytical results demonstrate that the excellent potential groundwater recharge zone was concentrated in the downstream region due to the distribution of gravelly stratum and agricultural land with high infiltration ability. Additionally, the concentration of drainage also helps the streamflow to recharge the groundwater system. The midstream region was less important, and was influenced by the sandstone with thick/thin shale of the Lushan Formation. Figure 7(f) shows the groundwater recharge potential diagram of the study area.

\subsection{Stable base-flow (SBF) analysis}

The method for the SBF model aims at separating the base-flow from a streamflow hydrograph in order to evaluate the discharge drained from groundwater to a stream. The method was based on the assumption that base-flow (groundwater discharge) was equal to the streamflow on days that fit the requirement of antecedent recession. For those days that did not fit this requirement, this method calculated the base-flow by linear interpolation, and separated the stream flow hydrograph into two parts: the base-flow and surface runoff. The affected time of surface runoff at the recession period was calculated from equation (6). To estimate the annual groundwater recharge, the daily streamflow for the $\mathrm{Da}-\mathrm{Du}$ Bridge gauging station in the $\mathrm{Wu}$ River watershed was collected from 1966 to 2003 (see figure 2). Figure 8 shows the monthly average streamflow and monthly average base-flow. Chen and Lee (2003) and Lee et al. (2006) pointed out that groundwater recharge might be overestimated when base-flow separation is applied in a mountainous region such as central Taiwan. In order to avoid this problem, SBF analysis is considered while analyzing the base-flow data. They also indicated that SBF analysis can obtain a more reasonable result. In this case, the minimum accumulation of recharge depths was fitted by linear regression during the low-flow period and the SBF period since it better represented the stable base-flow point. Figure 9 indicates that the annual recharge depth (stable point) was $851.2 \mathrm{~mm} /$ year. The annual groundwater recharge can be obtained from equation (8):

$$
R_{g w}=h \times A_{i},
$$

where $R_{g w}$ is the annual groundwater recharge $\left[\mathrm{L}^{3}\right]$; $h$ is the depth of annual recharge [L], and $A_{i}$ is the drainage area $\left[\mathrm{L}^{2}\right]$.

From the SBF model, the average of the groundwater recharge over 38 years (1966-2003) in the $\mathrm{Wu}$ River basin was found to be $1.72 \times 10^{9} \mathrm{~m}^{3}$ /year. The results indicated that the SBF model estimates a continuous or daily record of base flow under the streamflow hydrograph. In other words, it required an extended period of recording effort for the purpose of estimating the long-term groundwater discharge, as well as a variety of manual methods or a rapid analysis, and eliminated some

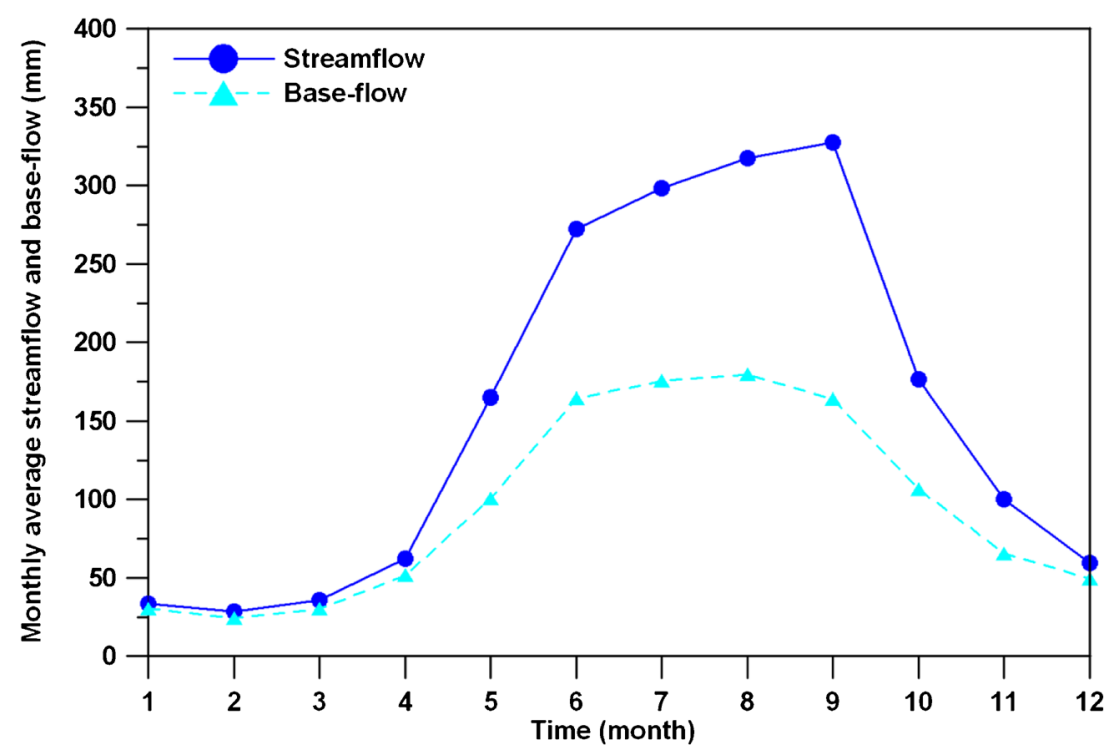

Figure 8. Result of monthly mean base-flow separation at Da-Du Bridge gauging station of Wu River basin, $1966-2003$. 


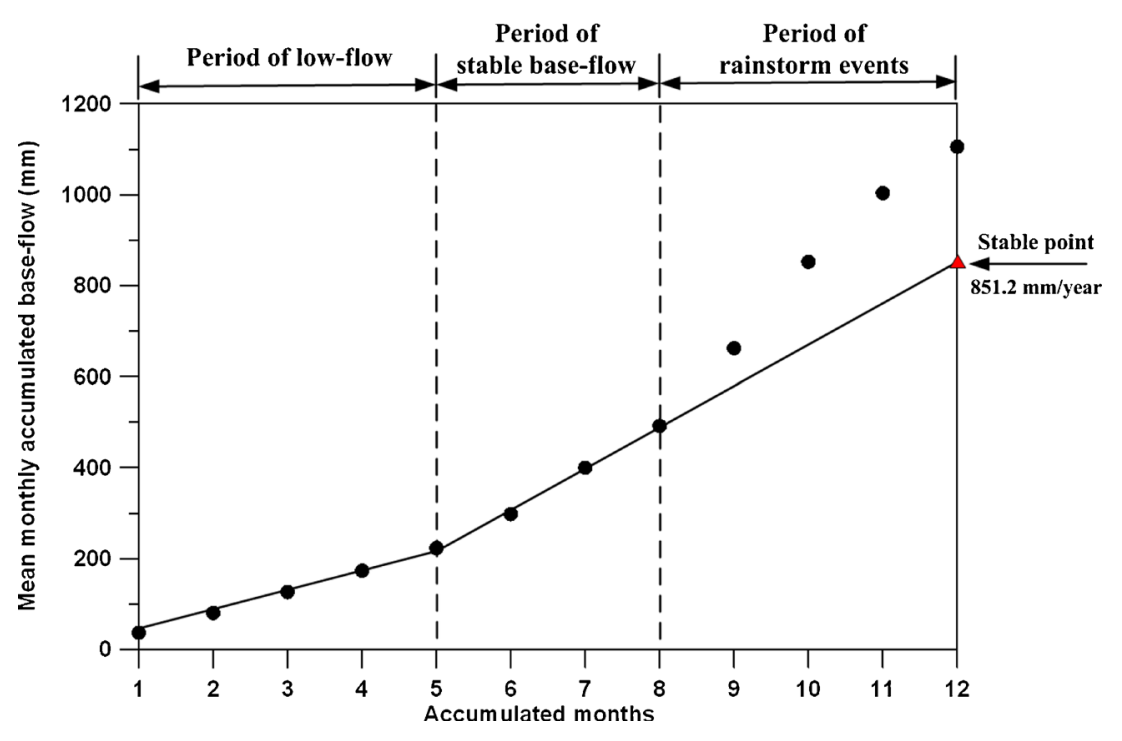

Figure 9. Result of stable base-flow analysis.

elements of subjectivity in the SBF model research. It is preferable but not required, that the record of daily mean streamflow is at least several years in duration. Results were useful if the computer programs being used were executed to give longterm (at least yearly) data. In the application of the methods for estimating either recharge or discharge, it is preferable that the record is complete for each year in the period of analysis. As mentioned, it has to be stressed that the analysis must be based on the basic assumptions of a base-flow model. The base-flow model was intended for the analysis of the groundwater flow system of a watershed for which a stream gauging station at the downstream end can be considered the only point of outflow. The recharge value from the base-flow model was represented as mean value of a basin.

\section{Summary and conclusions}

In this study, an integrated approach for assessing the characteristics of groundwater recharge using GIS and SBF techniques was proposed for the $\mathrm{Wu}$ River watershed, central Taiwan. First, this study produced a groundwater recharge potential map of the mountainous basin. The results indicated that the most effective groundwater recharge potential zone was located downstream. In this region, the gravelly stratum and agricultural land have high infiltration ability. Additionally, the concentration of drainage also indicates the ability of streamflow to recharge the groundwater system. The midstream region was least effective for groundwater recharge, mainly due to its sandstone with thick/thin shale of the Lushan Formation. This study established the interrelationships between the groundwater recharge potential factors and the groundwater recharge potential scores from the general hydrology characteristics of Taiwan. Since the potential groundwater recharge was directly correlated with percolation, the established scores may be more accurate and objective if the rate of percolation and hydraulic conductivity of each recharge potential factor can be measured in a laboratory or on-site.

Second, this study used the water balance conceptual model in a mountainous basin to estimate the groundwater recharge. This study used an SBF model of streamflow information to carry out groundwater recharge calculations of a mountainous basin. From the results of base-flow separation, the SBF days for each basin cannot be obtained, leading to a higher result for the estimated groundwater recharge. Therefore, $\mathrm{SBF}$ analysis can obtain a more reasonable result. The base-flow model was intended for the analysis of the groundwater flow system of a basin for which a stream gauging station at the downstream end can be considered the only point of outflow and in which the water volume extracted by pumping will be negligible. Baseflow separation has the advantage of integrating groundwater recharge across an entire basin without complex hydrogeologic modelling and detailed knowledge of the soil characteristics.

\section{Acknowledgements}

The authors are very grateful to three anonymous reviewers for their constructive comments in greatly improving the manuscript. This study is financially supported by funds from the National 
Science Council (NSC), Taiwan, R.O.C., under grant NSC 101-2221-E-006-196-MY2 and Central Geological Survey of Taiwan under grant 1015226904000-02-02.

\section{References}

Arnold J G and Allen P M 1999 Automated methods for estimating baseflow and ground water recharge from streamflow records; J. Am. Water Resour. Assoc. 35 411-424.

Barnes B S 1939 The structure of discharge recession curves; Trans. Amer. Geophys. Union 20 721-725.

Chen W P and Lee C H 2003 Estimating ground-water recharge from streamflow records; Environ. Geol. 44 $257-265$.

Chenini I, Mammou A B and May M E 2010 Groundwater recharge zone mapping using GIS-based multi-criteria analysis: A case study in central Tunisia (Maknassy Basin); Water Resour. Manag. 24 921-939.

Cherkauer D S and Ansari S A 2005 Estimating ground water recharge from topography, hydrogeology and land cover; Ground Water 43 102-112.

Choi W, Galasinski U, Cho S J and Hwang C S 2012 A spatiotemporal analysis of groundwater level changes in relation to urban growth and groundwater recharge potential for Waukesha County, Wisconsin; Geographical Analysis 44 219-234.

Chowdary V M, Ramakrishnan D, Srivastava Y K, Chandran V and Jeyaram A 2008 Integrated water resource development plan for sustainable management of Mayurakshi Watershed, India using remote sensing and GIS; Water Resour. Manag. 23 1581-1602.

Dinesh Kumar P K, Gopinath G and Seralathan P 2007 Application of remote sensing and GIS for the demarcation of groundwater potential zones of a river basin in Kerala, southwest coast of India; Int. J. Remote Sens. $\mathbf{2 8}$ 5583-5601.

Eckhardt K 2012 Technical note: Analytical sensitivity analysis of a two parameter recursive digital baseflow separation filter; Hydrol. Earth Syst. Sci. 16 451-455.

Edet A E, Okereke C S, Teme S C and Esu E O 1998 Application of remote sensing data to groundwater exploration: A case study of the Cross River State, southeastern Nigeria; Hydrogeol. J. 6 394-404.

El-Baz F and Himida I 1995 Groundwater potential of the Sinai Peninsula, Egypt; Project Summary, AID, Cairo.

Freeze R A and Cherry J A 1979 Groundwater; Prentice-Hall Inc., Englewood Cliffs, NJ, USA.

Forkuor G, Pavelic P, Asare E and Obuobie E 2013 Modelling potential areas of groundwater development for agriculture in northern Ghana using GIS/RS; Hydrol. Sci. J. 58 437-451.

Greenbaum D 1985 Review of remote sensing applications to groundwater exploration in basement and regolith; British Geological Survey Report OD 85, 36p.

Gupta M and Srivastava P K 2010 Integrating GIS and remote sensing for identification of groundwater potential zones in the hilly terrain of Pavagarh, Gujarat, India; Water Int. 35 233-245.

Horton R E 1933 The role of infiltration in the hydrologic cycle; Trans. Am. Geophys. Union 14 446-460.

Hsu K C, Wang C H, Chen K C, Chen C T and Ma K W 2007 Climate-induced hydrological impacts on the groundwater system of the Pingtung Plain, Taiwan; Hydrogeol. J. 15 903-913.
Jaiswal R K, Mukherjee S, Krishnamurthy J and Saxena R 2003 Role of remote sensing and GIS techniques for generation of groundwater prospect zones towards rural development - an approach; Int. J. Remote Sens. 24 993-1008.

Jang C S, Chen S K and Kuo Y M 2013 Applying indicatorbased geostatistical approaches to determine potential zones of groundwater recharge based on borehole data; Catena 101 178-187.

Jha M K, Chowdhury A, Chowdary V M and Peiffer S 2007 Groundwater management and development by integrated remote sensing and geographic information systems: Prospects and constraints; Water Resour. Manag. 21 427-467.

Krishnamurthy J, Venkatesa Kumar N, Jayaraman V and Manivel M 1996 An approach to demarcate groundwater potential zones through remote sensing and geographic information system; Int. J. Remote Sens. 17 1867-1884.

Kulandaiswamy V C and Seetharaman S 1969 A note on Barnes' method of hydrograph separation; J. Hydrol. 9 $222-229$.

Lattman L H and Parizek R R 1964 Relationship between fracture traces and the occurrence of groundwater in carbonate rocks; J. Hydrol. 2 73-91.

Leblanc M, Leduc C, Razack M, Lemoalle J, Dagorne D and Mofor L 2003 Application of remote sensing and GIS for groundwater modeling of large semi-arid areas: Example of the Lake Chad Basin, Africa; In: Hydrology of Mediterranean and Semiarid Regions Conference, Montpieller, France, IAHS (Red Books Series), Wallingford, UK, 278 186-192.

Leduc C, Favreau G and Schroeter P 2001 Long-term rise in a Sahelian water table: The Continental Terminal in southwest Niger; J. Hydrol. 243 43-54.

Lee C H, Chen W P and Lee R H 2006 Estimation of groundwater recharge using water balance coupled with base-flow-record estimation and stable-base-flow analysis; Environ. Geol. 51 73-82.

Lee C H, Yeh H F and Chen J F 2008 Estimation of groundwater recharge using soil moisture budget method and base-flow model; Environ. Geol. 54 1787-1797.

Linsley R K Jr, Kohler M A and Paulhus J L H 1982 Hydrology for Engineers, 3rd edn, McGraw-Hill, New York.

Machiwal D, Jha M K and Mal B C 2011 Assessment of groundwater potential in a semi-arid region of India using remote sensing, GIS and MCDM techniques; Water Resour. Manag. 25 1359-1386.

McCallum J L, Cook P G, Brunner P and Berhane D 2010 Solute dynamics during bank storage flows and implications for chemical base flow separation; Water Resour. Res. 46 W07541.

Mukherjee P, Singh C K and Mukherjee S 2012 Delineation of groundwater potential zones in arid region of India - A Remote Sensing and GIS Approach; Water Resour. Manag. 26 2643-2672.

Mukherjee S 1996 Targeting saline aquifer by remote sensing and geophysical methods in a part of Hamirpur-Kanpur, India; Hydrogeol. J. 19 53-64.

Murthy K S R 2000 Groundwater potential in a semi-arid region of Andhra Pradesh - a geographical information system approach; Int. J. Remote Sens. 21 1867-1884.

O'Brien R J, Misstear B D, Gill L W, Deakin J L and Flynn R 2013 Developing an integrated hydrograph separation and lumped modelling approach to quantifying hydrological pathways in Irish river catchments; $J$. Hydrol. 486 259-270.

O'Leary D W, Friedman J D and Poh H A 1976 Lineaments, linear, lineations: Some standards for old terms; Geol. Soc. Am. Bull. 87 1463-1469. 
Olmsted F H and Hely A G 1962 Relation between Groundwater and Surface Water in Brandywine Creek Basin, Pennsylvania; US Geological Survey Professional Paper, 417-A, 21p.

Preeja K R, Sabu J, Jobin T and Vijith H 2011 Identification of groundwater potential zones of a tropical river basin (Kerala, India) using remote sensing and GIS techniques; J. Indian Soc. Remote Sens. 39 83-94.

Rahman A 2008 A GIS based DRASTIC model for assessing groundwater vulnerability in shallow aquifer in Aligarh, India; Appl. Geogr. 28 32-53.

Rutledge A T 1992 Methods of using streamflow records for estimating total and effective recharge in the Appalachian Valley and Ridge, Piedmont, and Blue Ridge physiographic provinces; In: Regional aquifer systems of the United States, aquifers of the southern and eastern states (eds.) Hotchkiss W R and Johnson A I, American Water Resources Association Monograph Series 17 59-73.

Rutledge A T 1993 Computer Programs for Describing the Recession of Ground-Water Discharge and for Estimating Mean Ground-Water Recharge and Discharge from Streamflow Records; U.S. Geological Survey, Water Resources Investigations Report 93-4121, 45p.

Rutledge A T 2000 Considerations for use of the RORA program to estimate ground-water recharge from streamflow records; U.S. Geological Survey Open-File Report, 00-156, 44p.

Rutledge A T 1998 Computer programs for describing the recession of ground-water discharge and for estimating mean ground-water recharge and discharge from streamflow records-update; U.S. Geological Survey, Water Resources Investigations Report 98-4148, 43p.

Saraf A K and Choudhury P R 1998 Integrated remote sensing and GIS for groundwater exploration and identification of artificial recharge sites; Int. J. Remote Sens. 19 $1825-1841$.

Saraf A K, Choudhury P R, Roy B, Sarma B, Vijay S and Choudhury S 2004 GIS based surface hydrological modelling in identification of groundwater recharge zones; Int. J. Remote Sens. 25 5759-5770.

Sener E, Davraz A and Ozcelik M 2005 An integration of GIS and remote sensing in groundwater investigations: A case study in Burdur, Turkey; Hydrogeol. J. 13 $826-834$.

Shaban A, Khawlie M and Abdallah C 2006 Use of remote sensing and GIS to determine recharge potential zone: The case of Occidental Lebanon; Hydrogeol. J. 14 433-443.

Shahid S, Nath S K and Roy J 2000 Groundwater potential modeling in a soft rock area using a GIS; Int. J. Remote Sens. 21 1919-1924.

Solomon S and Quiel F 2006 Groundwater study using remote sensing and geographic information system (GIS) in the central highlands of Eritrea; Hydrogeol. J. 14 1029-1041.

Stewart M, Cimino J and Ross M 2007 Calibration of base flow separation methods with streamflow conductivity; Ground Water 45 17-27.

Tweed S O, Leblanc M, Webb J A and Lubczynski M W 2007 Remote sensing and GIS for mapping groundwater recharge and discharge areas in salinity prone catchments, southeastern Australia; Hydrogeol. J. 15 75-96.

Wang C H 2007 The impacts of climate change on the groundwater environment of Taiwan; Bull. Central Geol. Surv. 18 239-255 (in Chinese with English abstract).

Wang C H, Kuo C H and Chang F C 2004 The changing face of the groundwater environment in Taiwan; Bull. Central Geol. Surv. 17 1-22 (in Chinese with English abstract).

Water Resources Agency (WRA) 2005 Hydrological Year Book of Taiwan; Republic of China Ministry of Economic Affairs, Republic of China, Taipei.

Yeh H F, Lee C H, Hsu K C and Chang P H 2009 GIS for the assessment of groundwater recharge potential zone; Environ. Geol. 58 185-195.

Zektser I S 2002 Principles of regional assessment and mapping of natural groundwater resources; Environ. Geol. 42 $270-27$. 